\title{
Morphology and Anatomy of the Flower and Anthesis of Metrodorea nigra St. Hill. (Rutaceae)
}

\author{
Luiz A. de Souza*, Ismar S. Moscheta, Káthia S. M. Mourão and Sonia M. da Rosa \\ Departamento de Biologia; Universidade Estadual de Maringá; lasouza@uem.br; Av. Colombo, 5790; 87020-900; \\ Maringá - PR - Brazil
}

\begin{abstract}
Studies on the morphology and anatomy of the flower and anthesis of Metrodorea nigra St. Hill. (Rutaceae) showed perfect flowers, which occurred in panicle. The peak of the flowering was August and September. The anthesis was diurnal and the species presented protandrous flowers. The green sepals and the red petals presented papillose epidermis with stomata and parenchymatic mesophyll. The tetrasporangiate anther presented a papillose epidermis too, endothecium cells with secondary parietal thickenings, two middle layers and binucleate tapetum. The only pistil presented an ovary wall with nectariferous tissue and a meristematic ventral epidermis, a solid style and an inconspicuous stigma. The ovules were anatropous, bitegmic and crassinucelate and presented an obturator of funicular and placentic origin. The nectaries occurred around the ovary as a disk-like structure and in its apex as a number of pillose protuberances.
\end{abstract}

Key words: Metrodorea nigra, Rutaceae, blossom, anthesis, protandry, flower structure

\section{INTRODUCTION}

Metrodorea nigra St. Hill., belonging to the Rutaceae family, is popularly known as "carrapateira" or "caputuna-preta". It is an arboreal species, four to five meters height, typical of the sub-canopy of the "Floresta Semidecídua" of the Paraná River basin and the "Floresta Pluvial Atlântica", both situated in Brazil. This species presents perennial leaves and growth preferentially in the shade and moist habitats. It is recommended for the densification of degraded forests in permanent preservation. Its wood is used in civil construction (Lorenzi, 1992). In some forests in Paraná State, Brazil, the immature seeds of $M$. nigra are used as food by monkeys.
Flowers of Rutaceae species are not well-known in their morphological and anatomical aspects. However, the anatomy and vascularization of the flower of Pilocarpus organensis was described by Marquete (1981), the flower morphology of Zanthoxylum piperitum and Fagara mantchurica by Kim et al. (1995) and the ovule structure in studies of fruit and seed development by Boesewinkel (1977, 1978), Boesewinkel and Bouman (1978) and Beltrati (1991). Studies about floral biology included works of Crestana et al. (1983) with Esenbeckia leiocarpa, Piedade and Ranga (1994) with Galipea jasminiflora, Moreira and Arnaez (1994) with Zanthoxylum mayanum, Barbosa (1999) with Hortia brasiliana and the studies of Pombal and Morellato (2000) with two species of Metrodorea.

*Author for correspondence 
M. nigra occurs in the forest remnants of northwestern Paraná State, Brazil, a vast region which now a days presents less than $1 \%$ of the native forest cover. The deforestation that still occurs in this region threatens this and other native species, which present ecological and economical importance with extinction. Thus, studies about the reproduction process of these species are necessary. In this paper, morphological and anatomical aspects of the flowers, flowering time and anthesis of $M$. nigra are described and discussed.

\section{MATERIALS AND METHODS}

The "Horto Florestal Dr. Luiz Teixeira Mendes" is a 37 ha forest remnant situated in the city of Maringá, Paraná State, Brazil between the meridians $51^{\circ} 30^{\prime}$ and $54^{\circ} \mathrm{W}$ and the parallels $22^{\circ}$ $30^{\prime}$ and $24^{\circ} 30^{\prime} \mathrm{S}$, with an average altitude of 556 meters. In this area, eight specimens of M. nigra St. Hill. were selected randomly. Flowers collection and observations about flowering time were made in 1999 and 2000.

Three specimens, whose inflorescence and floral buds were previously marked, were chosen for the anthesis study. The period of flower anthesis, the time and type of anther dehiscence, the aspect of the stigma and the insect visitors were observed and characterized during the anthesis in August 2000.

Analyses of the flower and floral bud were made in fresh and fixed material. Fixation took place in FAA 50 (Johansen, 1940). Permanent and semipermanent slides were prepared according to standard procedures (Johansen, 1940; Dnyansagar, 1958). Specific color tests for cellulose, tannin and lipids were carried out according to methodology described by Johansen (1940), Rawlins and Takahashi (1952) and Berlyn and Mikshe (1976), respectively. Vouchers of the studied species were deposited in the Herbarium of the Universidade Estadual de Maringá, under numbers HUM 5486 and 5487.

\section{RESULTS}

\section{Flower morphology}

The flowers occurred in axillary or apical panicles and in stem regions without leaves. The short axes were undivided or when divided, three brunches were present (Figs. 3 and 4). The average number of flowers per inflorescence was 59.4 with a minimum of 30 and a maximum of 123. However, just one or two (rarely more) fruits developed per inflorescence. The flowers presented a very weak smell, almost imperceptible. They were perfect, pentamerous, dichlamydeous, heterochlamydeous, hypogynous and actinomorphic. The green calyx was concisely gamosepalous and the red corolla was dialipetalous (Figs. 3 and 4). The flower presented just one red pistil with five carpels and locules (Fig. 8) and five stames (Fig. 4) with longitudinal opening. Nectaries occurred around the ovary as a disk-like structure and in its apex as a number of pillose protuberances (Fig. 1).

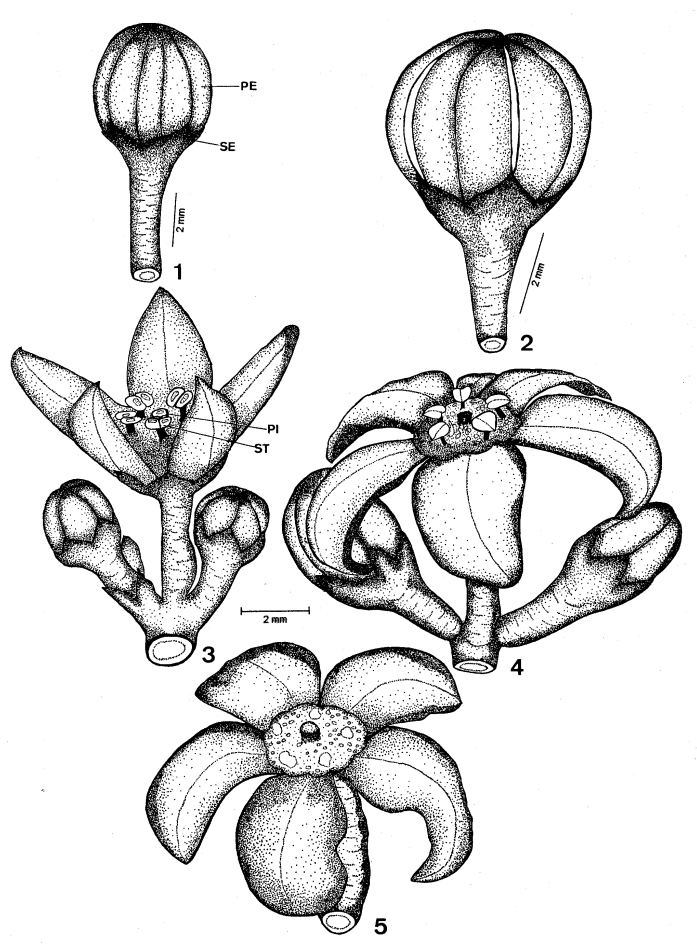

Figures 1-5 - Anthesis. 1. Floral bud; 2. Floral bud showing longitudinal rifts; 3-4. Open flowers; 5. Open flower in which the stamens have fallen. $(\mathrm{PE}=$ petal; $\mathrm{PI}=$ pistil; $\mathrm{SE}=$ sepal; $\mathrm{ST}=$ stamen $)$

\section{Flowering Time and Anthesis}

Flowering time began in July or August and lasted until December or January of the next year. The peak occurred in August and September. Anthesis was diurnal and occurred in the morning and late afternoon. The green floral buds showed red 
nuances; and when anthesis approached, the corolla became red. Flower opening began with the appearance of rifts at the base of the corolla of the floral bud (Figs. 1 and 2). Subsequently, the rift advanced in the direction of the flower apex, promoting petal separation and exposition of the anthers and stigma. After opening, the petals gradually and slowly assumed a horizontal position (Figs. 3 and 4). Anther opening was longitudinal and the rift appeared in the floral bud stage. Some flowers presented anthers whose opening occurred in the pre-anthesis stage. The stigma presented a dry and opaque surface during and after anther opening. The surface usually became receptive after the anthers fall (Fig. 5) or after the centrifugal bending of the filaments that positioned anthers, almost without pollen, among the petals. Thus, the petals and the anthers stayed horizontal, leaving the bright stigma free. In the morning, nectar production was copious, but floral buds with basal rifts and nectar were observed in the late afternoon. A few insects were observed visiting the flowers. Only those insects belonging to Diptera, which collected the nectar of the flowers, were registered.

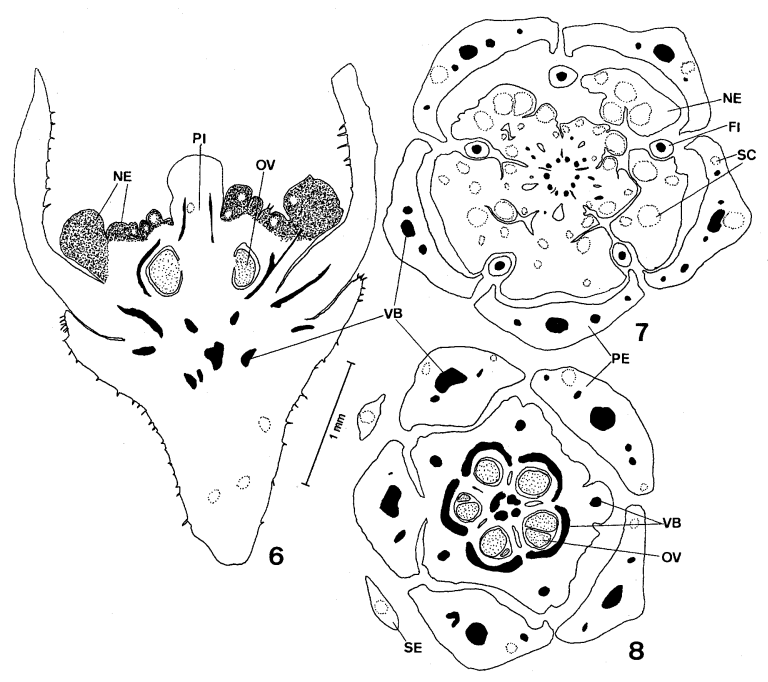

Figures 6-8 - Diagrams of floral bud. 6. Median longitudinal section; 7. Median transverse section; 8. Basal transverse section. ( $\mathrm{FI}=$ filament; $\mathrm{NE}=$ nectary; $\mathrm{PE}=$ petal; $\mathrm{SE}=$ sepal; OV = ovule; $\mathrm{SC}=$ secretory cavity; $\mathrm{VB}=$ vascular bundle).

\section{Flower anatomy}

Sepals (Fig. 9) presented an uniseriate epidermis, which showed stomata and tabular cells only on their adaxial surface. On the abaxial surface, the cells were wider and occur as pointed uni or bicellular non-glandular trichomes, which were accumulated on the margin. The mesophyll was parenchymatic, presented conspicuous intercellular spaces, and on the adaxial surface, cells varied from more or less spherical to elongated in shape. Cells presented chloroplasts, which were more abundant in subepidermal cell layers. Wide secretory cavities were immersed in the parenchymatic mesophyll. Vascularization was made by small collateral vascular strands, situated next to the adaxial surface of the epidermis.

Petals (Figs. 7, 8 and 10) presented a single epidermis, stomata and trichomes analogous to the sepals, which occurred on both surfaces. Their cells were more cylindrical on the adaxial surface. The hypodermis, whose cells contained anthocyanins and wide secretory cavities, occurred in the homogeneous and spongy parenchymatic mesophyll. Vascularization was made by a wide central collateral strand and by a number of smaller ones.

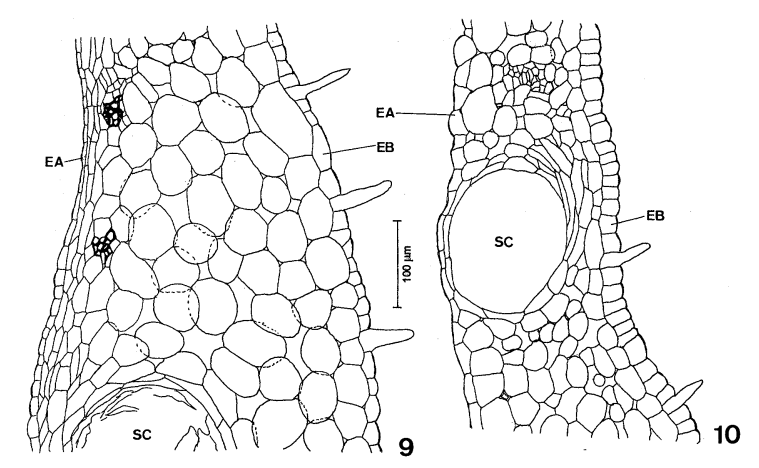

Figures 9-10 - Perianth in longitudinal section. 9. Sepal; 10. Petal. $(\mathrm{EA}=$ adaxial epidermis; $\mathrm{EB}=$ abaxial epidermis; $\mathrm{SC}=$ secretory cavity)

Anthers were tetrasporangiate (Fig. 12); and when immature, constituted by a uniseriate epidermis, an endothecium, two middle layers and secretory tapetum with binucleate cells (Fig. 11). In maturity, the epidermis became papillose with a striate cuticle and the endothecium presented one or more layers with parietal thickenings like edges; in this phase the middle layers and the tapetum were crushed 
(Figs. 12 and 13) and disintegrated. Crystalliferous parenchymatic cells occurred in the stomium. Endothecium cells were not only restricted to the pollen sac wall, but occurred in nearly every anther (Fig. 12). There were no secretory cavities in the anthers. Pollen grains were arranged in tetrahedrontype tetrads (Fig. 11).

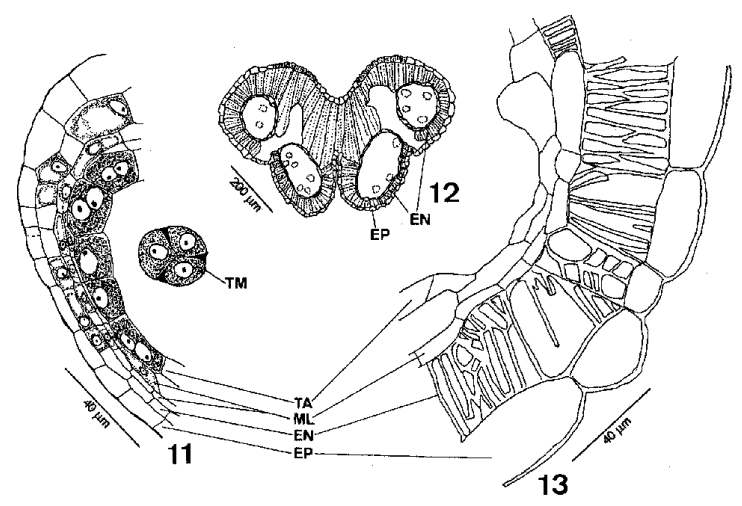

Figures 11-13 - Anther in transverse section. 11. Young anther wall; 12. Diagram of mature anther; 13. Detail of its wall. $(E N=$ endothecium; $\mathrm{EP}=$ epidermis; $\mathrm{ML}=$ middle layers; $\mathrm{TA}=$ tapetum; $\mathrm{TM}=$ tetrad of microspores).

Filaments presented a single and glabrous epidermis. Below the epidermis, the parenchymatic tissue of the filament presented the first layer with cells rich in anthocyanin. There was a single central vascular bundle (Fig. 7).

The ovary wall was almost completely constituted by nectariferous or secretory tissue (Fig. 6). Protuberances covered by the epidermis with a striate cuticle and a non-glandular trichome occurred in the upper region of the ovary. Wide secretory cavities occurred in the parenchymatic ovarian mesophyll (Fig. 14). These cavities did not occur in the basal region, in which could be observed collateral vascular bundles immersed in the parenchyma. In this region, petals and filaments were adnate to the ovary wall (Fig. 8). The ventral epidermis was uniseriate and cells were slightly cylindrical or tabulate in shape. Periclinal divisions could be observed in the epidermis during the pre-anthesis (Fig. 14).

The style was solid and presented a single and glabrous epidermis (Fig. 15). Both the epidermis and subepidermal layers showed anthocyanin. The central transmitting tissue was constituted by thin- walled cells with conspicuous nuclei and inconspicuous vacuoles (Fig. 16). Vascularization was made by eight vascular bundles, two for each carpel leaf (Fig. 15). The inconspicuous stigma (Fig. 6) presented secretory epidermis constituted by short trichomes, usually unicellular with rounded edges (Fig. 17).

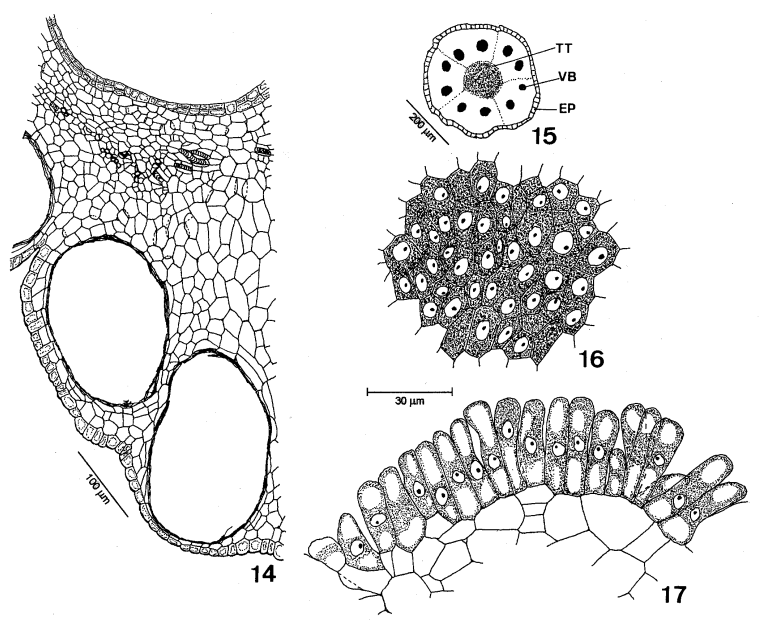

Figures 14-17 - Pistil. 14. Detail of ovary wall in transverse section; 15. Diagram of style in transverse section; 16. Detail of the transmitting tissue; 17. Stigma epidermis. $(\mathrm{EP}=$ epidermis; $\mathrm{TT}=$ transmitting tissue; $\mathrm{VB}=$ vascular bundle).

Ovules were anatropous and bitegmic (Figs. 18 and 19). Both integuments presented cuticle. The inner integument showed two or three cell layers and the outer three layers or more. Ovules were also crassinucelate, presenting a number of cell layers between the nucellar epidermis and the megaspore. Periclinal divisions were evident in the nucellar epidermis (Fig. 18). Ovules had an obturator of placental and funicular origin constituted by long uni or bicellular trichomes (Fig. 19). Nectaries occurred as a disk-like structure in the wall at the base of the ovary and in the apex as a number of pillose protuberances (Figs. 6 and 7). Epidermal cells were prismatic or tabulate in shape. Secretory tissue was parenchymatic and showed wide secretory cavities (Fig. 20). The vascular system was only constituted by phloem. 


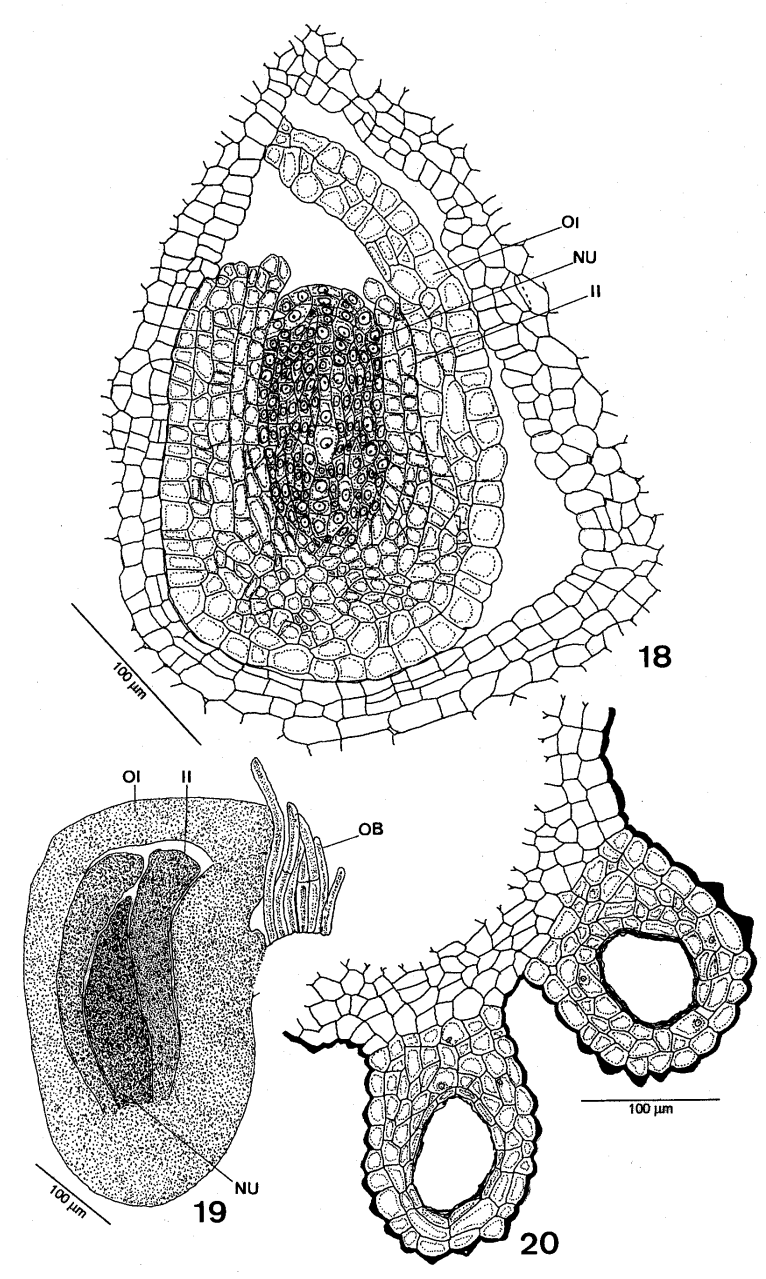

Figures 18-20 - Ovule and nectary. 18. Detail of ovule in longitudinal section; 19. Diagram of ovule and obturador; 20. Secretory cavities of nectary. (II = inner integument; $\mathrm{NU}=$ nucellus; $\mathrm{OB}=$ obturator; $\mathrm{OI}=$ outer integument).

\section{DISCUSSION}

Lloyd and Webb (1986) suggested that the separation of the presentation of pollen and stigmas in time often reduced self-fertilization. On the other hand, Bertin and Newman (1993) affirmed that protogyny could be, at least in part, a mechanism for reducing self-fertilization, but found no evidence that the same was true of protandry. Protandry has a marked incidence in Asteridae (Bertin and Newman, 1993) and it was as common as protogyny in biotically pollinated species (Lloyd and Webb, 1986).
Anther opening in $M$. nigra occurred early in the anthesis or even in the pre-anthesis phase. On the other hand, the stigma became bright and receptive just after the stamens lose or assumed a horizontal position, making any contact of the pollen with the stigma difficult. These observations suggested the occurrence of protrandrous flowers in $M$. nigra were in accordance with the descriptions of Pomball and Morellato (2000), who considered this species protandrous and self-incompatible.

Insects belonging to Diptera were observed visiting the flowers of $M$. nigra, confirming the recordings of Pombal and Morellato (2000) in semidecidual forests in Brazil. These authors considered the Diptera Pseudoptiloleps nigripoda (Muscidae) and Fannia sp (Fanniidae) the main pollinator agents in this type of vegetation.

The ventral meristem in the ovary of $M$. nigra emerged early, even in the pre-anthesis phase, and became evident by the periclinal divisions, which occurred in the ventral epidermis. Similar fact was observed in other species of Rutaceae and other families such as Lauraceae and Fabaceae, and could give rise to the endocarp (Souza, 1988; Souza and Moscheta, 2000). According to Maheshwari (1971) classification, the ovule of $M$. nigra was crassinucellate which presented well developed parietal tissue. However, periclinal cellular divisions in the apical cells of the nucellar epidermis were observed, which according to Davis (1966) characterized the ovule of the species as pseudocrassinucellate. Ovules of $M$. nigra presented an obturator of funicular and placental derivation, considered by Maheshwari (1971) an organ of special significance in facilitating the entry of the pollen tube into the ovule. The placental and funicular origin of the obturator seemed to be common in other species of Rutaceae (Boesewinkel, 1977, 1978; Boesewinkel and Bouman, 1978; Beltrati, 1991).

\section{RESUMO}

Metrodorea nigra St. Hill. (Rutaceae) apresenta flores perfeitas que ocorrem em panícula. O pico de florescimento acontece em agosto e setembro. A antese é diurna e a espécie apresenta flores protândricas. As sépalas verdes e as pétalas vermelhas apresentam epiderme papilosa contendo estômatos e mesofilo parenquimático. A antera tetrasporangiada também apresenta uma epiderme papilosa, células do endotécio com espessamento 
parietal secundário, duas camadas médias e tapetum binucleado. $\mathrm{O}$ único pistilo apresenta a parede do ovário com tecido nectarífero e uma epiderme ventral meristemática, um estilete sólido e um estigma imperceptível. Os óvulos são anátropos, bitegumentados e crassinucelados e apresentam um obturator de origem funicular e placentária. O nectário, em forma de disco, circunda a base do ovário e em seu ápice há várias protuberâncias pilosas.

\section{REFERENCES}

Barbosa, A. A. A. (1999), Hortia brasiliana Vand. (Rutaceae): polinização por aves Passeiriformes no cerrado do sudeste brasileiro. Rev. Bras. Bot., 22 : (1), 99-105.

Beltrati, C. M. (1991), Estudo morfoanatômico das sementes e plântulas de Esenbeckia febrifuga (St. Hill.) A. Juss. ex Mart. (Rutaceae). Naturalia, 16, 161-169.

Berlyn, G. P. and Miksche, J. P. (1976), Botanical microtechnique and citochemistry. Ames, Iowa : The Iowa State University Press. pp. 275-279.

Bertin, R. I. and Newman, C. M. (1993), Dichogamy in angiosperms. Bot. Rev., 59 : (2), 112-152.

Boesewinkel, F. D. (1977), Development of ovule and testa in Rutaceae I: Ruta, Zanthoxylum, and Skimmia. Acta Bot. Neerl., 26 : (3), 193-211.

Boesewinkel, F. D. (1978), Development of ovule and testa in Rutaceae III. Some representatives of the Aurantioideae. Acta Bot. Neerl., 27 : (5/6), 341-354.

Boesewinkel, F. D. and Bouman, F. (1978), Development of ovule and testa in Rutaceae II: The unitegmic and pachychalazal seed of Glycosmis CF. arborea (Roxb.) D.C. Acta Bot. Neerl, 27 : (1), 69-78.

Crestana, C. S. M.; Dias, I. S. and Kageyama, P. Y. (1983), Biologia floral do guarantã (Esenbeckia leiocarpa Engl.). Silvicultura, 28, 35-38.

Davis, G. L. (1966), Systematic embryology of the angiosperms. New York : John Wiley and Sons.

Dnyansagar, V. R. (1958), Embryological studies in the Leguminosae VIII. Acacia auriculaeformis A Cunn., Adenanthera pavonina Linn., Calliandra grandiflora Benth. Lloydia, 21 : (1), 1-25.

Johansen, D. A. (1940), Plant microtechnique. New York : McGraw-Hill Book Company. pp. 27-203.

Kim, H.; Shin, H.; Sun, B. Y.; Kim, H. and Choi, H. K. (1995), Reproductive characters of Zanthoxylum piperitum DC. and Fagara mantchurica (Benn.) Honda in Korea. Korean. J. Plant Taxon., 25 : (3), 195-207.

Lloyd, D. G. and Webb, C. J. (1986), The avoidance of interference between the presentation of pollen and stigmas in angiosperms - I. Dichogamy. New Zeal. J. Bot., 24, 135-162.
Lorenzi, H. (1992), Árvores brasileiras: manual de identificação e cultivo de plantas arbóreas nativas do Brasil. Nova Odessa : Editora Plantarum. pp. 309.

Maheshwari, P. (1971), An introduction to the embryology of angiosperms. New Delhi, Tata McGraw-Hill Publishing Company, pp. 185-187.

Marquete, O. (1981), Anatomia e vascularização foliar e floral de Pilocarpus organensis Occhioni and Rizzini (Rutaceae). Arq. Jard. Bot. Rio J., 25, 117-159.

Moreira, G. I. and Arnaez, S. E. (1994), Morphology of reproductive structures and germination of nine native forestry species in Costa Rica. Rev. Biol. Trop., 42 : (2), 73-82.

Piedade, L. H. and Ranga, N. T. (1994), The pollination ecology of Galipea jasminiflora Engler (Rutaceae). Rev. Bras. Bot., 16 : (2), 151-157.

Pombal, E. C. P. and Morellato, L. P. C. (2000), Differentiation of floral color and odor in two fly pollinated species of Metrodorea (Rutaceae) from Brazil. Plant Syst. Evol., 221 : (3-4), 141-156.

Rawlins, T. E. and Takahashi, W. N. (1952), Technics of plant histochemistry and virology. Millbrae : The National Press. pp. 1-75.

Souza, L. A. (1988), Anatomia de estádios de desenvolvimento da semente de Lonchocarpus muehlbergianus Hassl. (Leguminosae-Faboideae). Garcia de Orta Ser. Bot., 10 : (1-2), 1-9.

Souza, L. A. and Moscheta, I. S. (2000), Morfo-anatomia do desenvolvimento do fruto de Ocotea puberula (Rich.) Nees e de Nectandra megapotamica (Spreng.) Mez (Lauraceae). Acta Cient. Venez., 51 : (2), 84-89.
Received: March 22, 2002; Revised: October 09, 2002; Accepted: March 19, 2003. 